\title{
TREEHOPPERS (HOMOPTERA, MEMBRACIDAE) IN SOUTHEASTERN BRAZIL: USE OF HOST PLANTS
}

\author{
Benedito C. Lopes ${ }^{1}$
}

\begin{abstract}
A survey on the use of host plants by treehoppers in plants in cerrado (savanna) vegetation at Moji-Guaçu (São Paulo. Southeastern Brazil) was made. Fifty-two species of treehoppers were recorded in association with 40 host plant species from October 1980 to February 1982. The families Araliaceac, Asteraceac. Leguminosae, Malpighiaceae, Myrtaceae and Nyctaginaceae were the most commonly used for oviposition. Byrsonima intermedia A. Juss. (Malpighiaceae) had the highest number of associated treehopper species ( 10 species). The abundance of treehopper individuals was related to the hot and rainy season (from Octoher to Fehruary), while during the cold and dry season (from March to September) there was a decrease in the number of these Homoptera. After the oceurrence of a frost. few adults and nymphs were observed on the host plants for one to two months.

KEY WORDS. Homoptera, Memhracidae, trechoppers, savanna. Brazil
\end{abstract}

The treehoppers (Homoptera, Membracidae) are phytophagous insects that suck sap from the host plants showing a preference for its younger and tender parts; thus, they are found at the base of petioles and veins of leaves, the apical branch meristem, inflorescences, and green fruits (HAVILLAND 1925; FUNKHOUSER 1950).

The family Membracidae has been poorly studied in Brazil except for taxonomic works. The ecological aspects of this group, especially host plant associations, are relatively unknown. This is particularly true for the region of the Brazilian cerrado (savanna) (LOPES 1984).

The goals of this work were to assess host plant associations of treehoppers in the cerrado vegetation, and to investigate the seasonal variation in abundance.

\section{METHODS}

The sampling was done between October, 1980 and February, 1982, in an area of cerrado of the Reserva Biológica de Moji-Guaçu (RBMG, São Paulo) $22^{\circ} 11-18^{\circ} \mathrm{S}, 47^{\circ} 07-10^{\prime} \mathrm{W}$. (EITEN 1971). Nine transects were installed distancing about $100 \mathrm{~m}$ from each other (Fig. 1). The transects 1 to 3 were about $200 \mathrm{~m}$ long, while the rest were about $500 \mathrm{~m}$ long. The marked plants, selected at random, ranged from a minimum height of $30-40 \mathrm{~cm}$ and a maximum height of $200 \mathrm{~cm}$. The distance between each plant along the transects ranged from $0.5 \mathrm{~m}$ to $3.0 \mathrm{~m}$. There

1) Departamento de Biologia. Centro de Ciências Biológicas, Universidade Federal de Santa Catarina. Caixa Postal 476. 88040-900 Florianópolis. Santa Catarina. Brasil. 

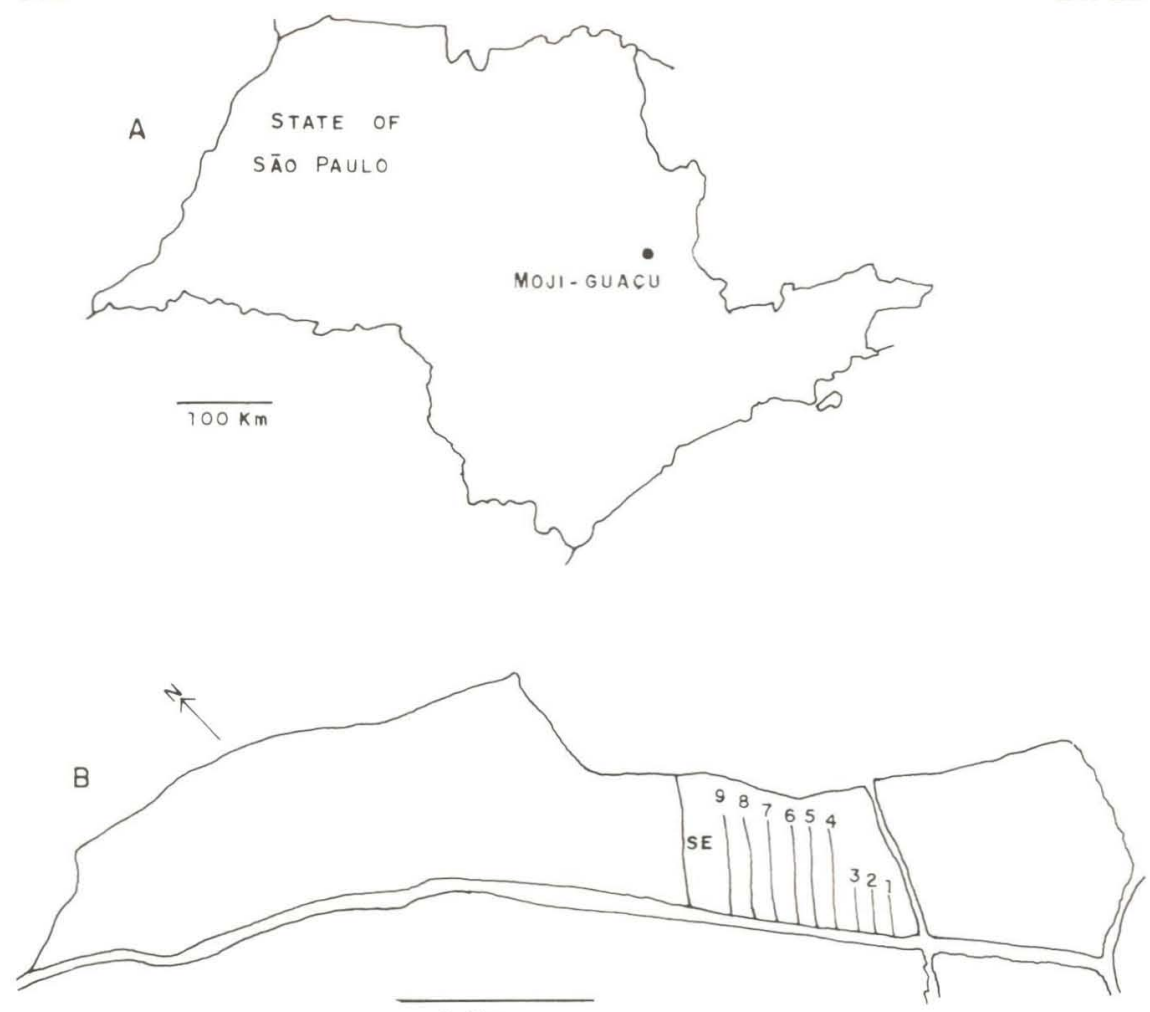

$1 \mathrm{~km}$

Fig. 1. Maps showing (A) the São Paulo state and the location of Moji-Guaçu City, and (B) the Reserva Biológica de Moji-Guaçu (RBMG) with the nine transects installed at the Setor de Ensino (SE).

were up to 50 individuals in the first three transects, and about 150 individuals in transects 4 to 9, adding up to 1025 marked plants observed. Five surveys were made on the plants throughout the 17 months of the work. At the first survey the following data were recorded for each plant: code number of the plant; date; species; height; phenologic state (vegetative, flowers and/or fruits); absence or presence of treehoppers (nymphs and/or adults). During the following surveys the same data were recorded, except the plant species and its height. The treehoppers were identified in the field or collected manually to be identified later. The transects were assembled at the Setor de Ensino (SE) of the RBMG, in accordance to the directions of VuONO et al. (1981). below:

The frequency of treehoppers on host plants was calculated by the relation 


\section{RESULTS AND DISCUSSION}

A total of 1025 plants, belonging to 93 different species, were marked. Table I shows the recorded plant species, the number of individuals of each plant species and their associated treehopper species.

Of the 93 plant species examined, 40 (43\%) were observed with treehoppers. On 17 of these latter ones, adults, eggs and nymphs were found while on 23 plant species only adults were found.

The plant families most frequently used by treehoppers for oviposition in the cerrado are: Araliaceae; Asteraceae; Leguminosae; Malpighiaceae; Myrtaceae; and Nyctaginaceae. Of the 26 treehopper species observed and/or collected, 11 were found as eggs and/or nymphs, enabling the establishment of ovipositional hosts for $42.3 \%$ of treehoppers. Two of the families listed above - Asteraceae and Leguminosae - are cited by FUNKHOUSER $(1917,1950)$ as being among the most used families for oviposition in temperate regions. In addition to the above families, STRÜMPEL (1972) mentions that South American treehoppers can be found on the families Flacourtiaceae, Guttiferae, Melastomataceae, Monimiaceae, Rubiaceae, Sapindaceae, and Solanaceae, all of them represented in the cerrado.

For the 40 plant species (Tab. II), disregarding the ones represented by only one or two individuals in the transects, the most commonly used plant species by treehoppers were: Byrsonima intermedia A. Juss. (Malpighiaceae) $(36.00 \%)$; Eupatorium maximiliani Schrad. ex DC. (Asteraceae) (21.05\%); Siparuna guianensis Aubl. (Monimiaceae) (20.00\%); Eugenia bimarginata DC. (M yrtaceae) (17.14\%); Neea theifera Oerst. (Nyctaginaceae) (14.84\%); Guapira noxia (Netto) Lundell (Nyctaginaceae) (11.11\%); Gochnatia pulchra Cabr. (Asteraceae) (10.83\%); Gochnatia harrosii Cabr. (Asteraceae) (10.67\%); and Myrcia albo-tomentosa DC. (Myrtaceae) (10.00\%). Each of the remaining species had association levels bellow $10.00 \%$.

Byrsonima intermedia, a species of broad geographic distribution (LORENZI 1982), bears flowers and fruits during eight months of the year. Since many treehoppers appear to feed preferentially on peduncles, this may explain why this host presents a greater abundance of treehopper species. B. intermedia has ten associated treehopper species, followed by $G$. barrosii (seven species), G. pulchra (five species), $N$. theifera (four species), and E. maximiliani (three species) (Tab. III).

Some treehopper species have a strong association with certain host plants while others do not (Tab. IV), therefore being accounted as mild polyphagous (WOOD 1993). Individuals of Guayaquila xiphias (Fabricius, 1803) were found in an almost exclusive association with Didymopanax vinosum (Cham. \& Schlecht) March (Araliaceae); Erechric sp. 2 associated mainly with Guapira noxia and Neea theifera, both belonging to the family Nyctaginaceae, and also associated with Byrsonima intermedia; Tylopelta sp. 1 associated with Miconia albicans (Sw.) Triana (Melastomataceae), and Cyphonia capra Burmeister, 1833 associated almost exclusively with species of the family Asteraceae, notedly Eupatorium maximiliani. Asteraceae seems also to be the family of preference for Bolhonota 
Table I. Species of cerrado plants studied at the Reserva Biológica de Moji-Guaçu. Bet ween brackets is the number of individuals marked. On the column of treehoppers species, * means only adults present, and ${ }^{x}{ }^{*}$ means eggs and/or nymphs.

\begin{tabular}{ll}
\hline \multicolumn{1}{c}{ Monocotyledoneae } & Treehopper species \\
\hline Arecaceae & - \\
Attalea humilis Mart. (6) & Cyphonia capra (Burmeister, 1833) - \\
Butia leiospatha (Mart.) Becc. (4) & - \\
Diplothemium campestre Mart. (3) & \\
\hline \multicolumn{2}{c}{ Dicotyledoneae flexuosa (Mart.) Becc. (7) }
\end{tabular}

Annonaceae

Annona coriacea Mart. (2)

Xylopia aromatica (Lam.) Mart. (18)

Membracis dorsata Fabricius, 1803 .

Apocynaceae

Aspidosperma tomentosum Mart. (55)

Hancornia speciosa Gomez (3)

Araliaceae

Didymopanax macrocarpum (Cham. \& Schlecht.) Seem (12)

Didymopanax vinosum (Cham. \& Schlecht.) March (27)

Asteraceae

Baccharis dracunculifolia DC. (8)

Eremanthus sphaerocephalus Baker (1)

Eupatorium maximiliani Schrad. ex DC. (19)

Eupatorium squalidum DC. (2)

Eupatorium vauthierianum DC. (1)

Gochnatia barrosii Cabr. (30)

Gochnatia puichra Cabr. (24)

Piptocarpha rotundifolia (Less.) Baker (8)

Vernonia ferruginea Less. (1)

Vernonia rubriramea Mart. (17)

Bignoniacese

Arrabidaea brachypoda (DC.) Bur. (6)

Tabebuia caraiba (Mart.) Bur. (21)

Membracis tectigera Olivier, 1792 ..

Guayaquila xiphias (Fabricius, 1803) *

Membracis richteri Fonseca, 1949 *

Guavaquila xiphias * *

Bolbonota melaena (Germar, 1835) - .

Cyphonia capra *

Cyphonia clavata (Fabricius, 1787) '

Cyphonia capra *

Bolbonota bituberculata Stäl, 1858 *

Bolbonota melaena *

Ceresa sp. 1 *

Cyphonia capra *

Enchenopa gracilis (Germar, 1821) *

Erechtia sp. 2 *

Membracis tectigera .

Bolbonota bituberculata *

Bolbonota melaena *

Guayaquila xiphias *

Hypsoprora albopleura Fonseca, 1933 *

Membracis tectigera ."

Bolbonota melaena.

Amastris sakakibarai Broomfield, 1976 *

Bolbonota melaena *

Cyphonia capra .

Cyphonia sp. *

Guayaquila xiphias .

Tabebuia ochracea (Cham.) Standl. (29)

Zeyhera digitalis (Vell.) Hoehne (1)

Bombacaceae

Eriotheca gracilipes (Schum.) A. Robyns (8)

Pseudobombax longiflorum (Schum.) A. Robyns (3)

Burserace ae

Protium heptaphyllum (Aubl.) March (1)

Caryocarace ae

Caryocar brasiliense Camb. 11

Revta bras. Zool. 12 (3): 595 - 608, 1995 
Table I. Continuation.

\begin{tabular}{cc}
\hline Dicotyledoneae & Treehopper species \\
\hline
\end{tabular}

Celastraceae

Austroplenckia populnea (Reiss.) Lund. (3)

Chrysobalanace ae

Couepla grandifiora (Mart. \& Zucc.) Benth. (4)

Connaraceae

Connarus suberosus Planch. (26)

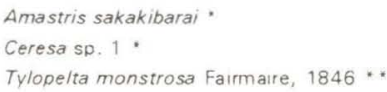

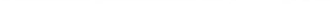

(20)

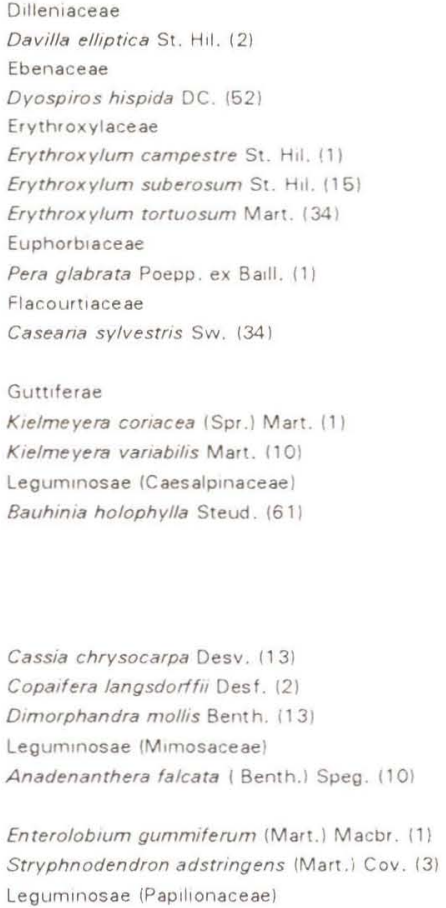

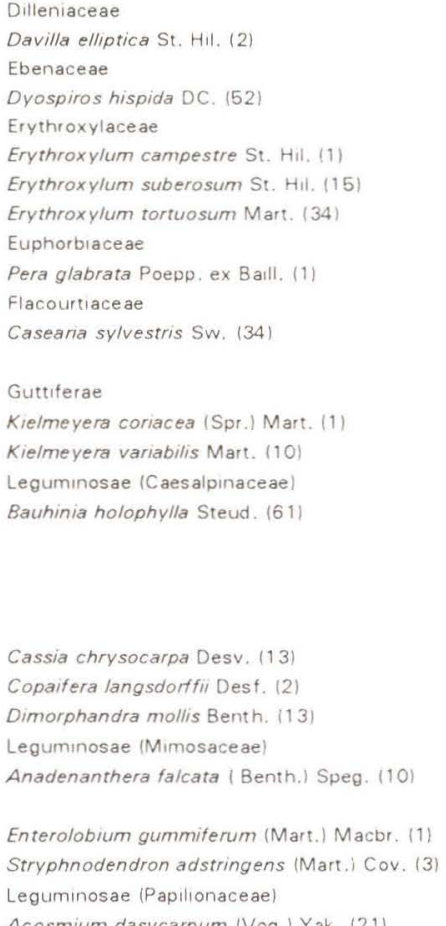 \\ Acosmium dasycarpum (Vog.) Yak. (21)
}


Table I. Continuation.

\begin{tabular}{l} 
Dicotyiedoneae \\
\hline Byrsonima intermedia A. Juss. (20) (cont.) \\
Byrsonima verbascifolia L. Rich. (3) \\
Heteropteris byrsonimifolia A. Juss. (1) \\
Melastomataceae \\
Leandra lacunosa Cogn. (5) \\
Miconia albicans (Sw.) Triana (46)
\end{tabular}

Miconia rubiginosa (Bonpl.) DC. (5)

Monimiaceae

Siparuna guianensis Aubl. (6)

\section{Moraceae}

Brosimum gaudichaudif Trec. (3)

Ficus citrifolia P. Miller (1)

Myrsinaceae

Rapanea guianensis Aubl. (35)

Rapanea lancifolia Mez (7)

Myrtaceae

Campomanesia cambessedeana Berg (23)

Eugenia aurata Berg (4)

Eugenia bimarginata DC. (7)

Eugenia livida Berg (2)

Myrcia albo-tomentosa DC. $(14)$

Myrcia lingua Berg (6)

Myrcia tomentosa (Aubl.) DC. (1)

Nyctaginaceae

Guapira noxia (Netto) Lundell (9)

Neea theifera Derst. (31)

Ochnaceae

Ouratea spectabilis (Mart.) Engl. (17)

Opiliaceae

Agonandra brasiliensis Miers (4)

Proteaceae

Roupala montana Aubl. (9)

Rubiaceae

Palicourea rigida H.B.K. (7)

Rudgea viburnioides (Cham.) Benth. (7)

Tocoyena brasiliensis Mart. (3)

Tocoyena formosa (Cham. \& Schlecht.) K. Schum. (10)
Treehopper species

Enchenopa gracilis .

Enchenopa monoceros '

Enchenopa sp. 3 .

Erechtia sp. 2 *

Hypsoprora albopleura.

Leioscyta sp. .

Tylopelta monstrosa ..

Tylopelta sp. $2^{*}$

Bolbonota bituberculata.

Calloconophora argentipennis .

Membracis tectigera .

Tylopelta sp. 1 .

Erechtia sp. 1 .

Sphongophorus sp. "

Amastris sakakibarai

Amastris sakakibarai *

Enchenopa gracilis *

Erechtia sp. 2 '

Cyphonia capra*

Erechtia sp. 2 '

Leioscyta sp. "

Erechtia sp. 2 *

Ceresa sp. 1 .

Bolbonota melaena *

Ceresa sp. 1 .

Erechtia sp. 2 .

Amastris sakakibarai *

Bolbonota melaena.

Erechtia sp. 2 .

Tylopelta monstrosa *

Ceresa sp. 1 .

Metcalfiella pertusa (Germar, 1835) ‥

Enchenopa monoceros .

(Cont.)

Revta bras. Zool. 12 (3): 595 - 608, 1995 
Table I. Continuation.

\begin{tabular}{|c|c|}
\hline Dicotyledoneae & Treehopper species \\
\hline \multicolumn{2}{|l|}{ Sapindace ae } \\
\hline Serjania erecta Radlk. (4) & \\
\hline \multicolumn{2}{|l|}{ Sapotaceae } \\
\hline Pouteria ramifiora (Mart.) Radlk. (3) & . \\
\hline \multicolumn{2}{|l|}{ Solanaceae } \\
\hline Solanum lycocarpum St. Hil. (1) & - \\
\hline \multicolumn{2}{|l|}{ Styracaceae } \\
\hline \multirow[t]{4}{*}{ Styrax ferrugineus Nees \& Mart. $(20)$} & Bolbonota melaena. \\
\hline & Ceresa sp. 1 * \\
\hline & Cyphonia capra. \\
\hline & Enchenopa sp. 3 . \\
\hline \multicolumn{2}{|l|}{ Verbenaceae } \\
\hline Aegiphila Ihotskyana Cham. (4) & - \\
\hline Lippia salviifolia Cham. (5) & - \\
\hline \multicolumn{2}{|l|}{ Vochysiaceae } \\
\hline Qualea grandiflora Mart. 1211 & \\
\hline Qualea multiflora Mart. (9) & Erechtia sp. 2 \\
\hline Vochysia tucanorum (Spr.) Mart. (7) & . $\quad-2$ \\
\hline
\end{tabular}

bituberculata Stål, 1858 and B. melaena (Germar, 1835) - again Eupatorium maximiliani, Gochnatia barrosii and G. pulchra.

Several treehopper species are restricted to only a few host plants, which are usually of the same family (BRUES 1972). Nevertheless, these treehoppers cannot be considered strictly monophagous because, according to WOOD (1993), this category is restricted to species associated with one single species of host plant throughout its geographic distribution. This category is better applied to treehoppers of temperate zones, since tropical treehoppers tend to: be polyphagous, use perenial or semi-perenial host plants, be social, be associated with ant mutualists and be multivoltine (WOOD 1984, 1993).

The species Entylia bactriana (Germar, 1833), a temperate region treehopper studied by WOOD (1977) in Ohio (U.S.A.), could only be found on Asteraceae. MatausCh (1910) states that the species of Entylia only occur on Asteraceae and specially on species of Eupatorium. At the cerrado of the RBMG and at Morro do Ferro (Poços de Caldas, Minas Gerais) (personal observation), Entylia gemmata (Germar, 1821) was collected primarily on Asteraceae (Ambrosia polystachia DC., Gochnatia barrosii, Mikania cordifolia (L.F.), Mikania sp., Senecio sp., and Viguiera sp.), but was also recorded twice on Solanum erianthum D. Don. (Solanaceae). An extreme case of treehopper feeding specialization are the three genera of the Centrodontini (Membracinae), which feed exclusively of Larrea tridentata (Sessé \& Moç. ex DC.) Cov. (Zygophyllaceae) (DerTz 1975).

Many species of treehoppers herein studied are very polyphagous and utilize a variety of host plants. Ceresa sp. I was sampled on nine species of host plants, which belonged to seven plant families; Amastris sakakibarai Broomfield, 1976 was sampled on eight species of plants of six families, and Enchenopa gracilis (Germar, 1821) associated with seven species of plants of four families, and even with oviposition on almost all seven species mentioned. DIETRICH \& DEITZ (1991) and WOOD (1993) have stated that the genera Bolbonota Amyot \& Serville, 1843, 
Calloconophora Dietrich, 1991 and Guayaquila Goding, 1920 can he considered generalists since many species are associated with two or more plant families. Though the treehoppers Bolbonota melaena, Cyphonia capra and Erechtia sp. 2 have been observed in association with nine, nine and eight different species of host plants, respectively, they appear to generally exhibit a localized preference for just a few species of the same plant family (Tab. IV).

Table II. Treehopper host plants and the frequency of treehoppers on them. Between brackets is the number of individuals marked of each plant species. Each individual was examined five times.

\begin{tabular}{|c|c|}
\hline Host plants & Frequency of treehoppers $(\%)$ \\
\hline Byrsonima intermedia (20) & 36.00 \\
\hline Eupatorium maximiliani (19) & 21.05 \\
\hline Eupatorium squalidum (2) & 20.00 \\
\hline Heteropteris byrsonimifolia (1) & 20.00 \\
\hline Machaerium acutifolium (1) & 20.00 \\
\hline Myrcia tomentosa (1) & 20.00 \\
\hline Pera glabrata (1) & 20.00 \\
\hline Siparuna guianensis (6) & 20.00 \\
\hline Vatairea macrocarpa (1) & 20.00 \\
\hline Eugenia bimarginata (7) & 17.14 \\
\hline Neea theifera (31) & 14.84 \\
\hline Guapira noxia (9) & 11.11 \\
\hline Gochnatia pulchra (24) & 10.83 \\
\hline Gochnatia barrosii $(30)$ & 10.67 \\
\hline Myrcia albo-tomentosa (14) & 10.00 \\
\hline Vernonia rubriramea (17) & 8.24 \\
\hline Didymopanax vinosum (27) & 8.15 \\
\hline Byrsomima coccolobifolia (14) & 5.71 \\
\hline Butia leiospatha (4) & 5.00 \\
\hline Didymopanax macrocarpum (12) & 5.00 \\
\hline Platypodium elegans (4) & 5.00 \\
\hline Miconia albicans (46) & 4.35 \\
\hline Anadenanthera falcata (10) & 4.00 \\
\hline Styrax ferrugineus $(20)$ & 4.00 \\
\hline Ouratea spectabilis (17) & 3.53 \\
\hline Arrabidaea brachypoda (6) & 3.33 \\
\hline Myrcia lingua (6) & 3.33 \\
\hline Bauhinia holophylla (61) & 2.95 \\
\hline Acosmium dasycarpum (21) & 2.86 \\
\hline Rudgea viburnioides (7) & 2.86 \\
\hline Piptocarpha rotundifolia (8) & 2.50 \\
\hline Connarus suberosus (26) & 2.31 \\
\hline Qualea multiflora (9) & 2.22 \\
\hline Xylopia aromatica (18) & 2.22 \\
\hline Kielmeyera variabilis $(10)$ & 2.00 \\
\hline Cassia chrysocarpa (13) & 1.54 \\
\hline Dimorphandra mollis (13) & 1.54 \\
\hline Casearia sylvestris (34) & 1.18 \\
\hline Erythroxylum tortuosum (34) & 1.18 \\
\hline Campomanesia cambessedeana (23) & 0.87 \\
\hline
\end{tabular}


Table III. Most frequent host plants for treehoppers in the Reserva Biológica de Moji-Guaçu. Between brackets is the number of observations for each species of treehopper.

\begin{tabular}{ll}
\hline \multicolumn{1}{c}{ Host plants } & \multicolumn{1}{c}{ Treehopper species } \\
\hline Byrsonima intermedia & $\begin{array}{l}\text { Tylopelta monstrosa (10), Erechtia sp. } 2 \text { (8), Enchenopa monoceros (6), Amastris } \\
\text { sakakibarai (3), Bolbonota melaena (3), Leioscyta sp. (2), Enchenopa gracilis (1), } \\
\text { Enchenopa sp. 3 (1), Hypsoprora sp. (1), Tylopelta sp. 2 (1) }\end{array}$ \\
Gochnatia barrosii & $\begin{array}{l}\text { Bolbonota melaena (7), Ceresa sp. 1 (3), Enchenopa gracilis (2), Bolbonota bituberculata } \\
\text { Gochnatia pulchra }\end{array}$ \\
Bolbonota melaena (8), Bolbonota bituberculata (2), Guayaquila xiphias (1), Hypsoprora \\
albopleura (1), Membracis tectigera (1) \\
Erechtia sp. 2 (20), Amastris sakakibarai (1), Bolbonota melaena (1), Tylopelta \\
monstrosa (1)
\end{tabular}

Table IV. Feeding preferences for some treehopper species at the Reserva Biológica de Moji-Guaçu. Between brackets is the number of times that the treehopper species was recorded on the host plant.

\begin{tabular}{|c|c|}
\hline Treehopper species & Host plants \\
\hline Bolbonota melaena & $\begin{array}{l}\text { Gochnatia pulchra (8), Gochnatia barrosii (7), Eupatorium maximiliani (6), Byrsonima } \\
\text { intermedia (3), Guapira noxia (1), Neea theifera (1), Piptocarpha rotundifolia (1). Styrax } \\
\text { ferrugineus (1), Vernonia rubriramea (1) }\end{array}$ \\
\hline Cyphonia capra & $\begin{array}{l}\text { Eupatorium maximiliani (13), Vernonia rubriramea (4), Erythroxylum tortuosum (2). } \\
\text { Eupatorium squalidum (2), Butia leiospatha (1), Dimorphandra mollis (1), Gochnatia } \\
\text { barrosii (1). Myrcia albo-tomentosa (1). Styrax ferrugineus (1) }\end{array}$ \\
\hline Erechtia sp. 2 & $\begin{array}{l}\text { Neea theifera (20), Byrsonima intermedia (8), Guapira noxia (3), Myrcia albo-tomentosa } \\
\text { (3), Eugenia bimarginata (1), Gochnatia barrosii (1), Myrcia lingua (1), Qualea multiflora } \\
\text { (1) }\end{array}$ \\
\hline Guayaquila xiphias & $\begin{array}{l}\text { Didymopanax vinosum (11), Didymopanax macrocarpum (2), Arrabidaea brachypoda (1). } \\
\text { Gochnatia pulchra (1) }\end{array}$ \\
\hline Bolbonota bituberculata & Gochnatia pulchra (2), Gochnatia barrosii (1), Heteropteris byrsonimifolia (1) \\
\hline Tylopelta sp. 1 & Miconia albicans (8), Machaerium acutifolium (1) \\
\hline Erechtia sp. 1 & Siparuna guianensis (5) \\
\hline
\end{tabular}

The percentage of plants with treehoppers tends to increase during the rainy season, from October to February every year, and tends to fall to low numbers from March to September, when the weather is drier and colder (Fig. 2). During the rainy season there is a higher rate of plants sprouting anew, flowering and fruiting on cerrado (RIZZINI 1979). These events are suitable for feeding and breeding for the adult treehoppers. TSAI \& KOPP (1981), in their study on two species of treehoppers (Acutalis tartarea Say, 1830 and Micrutalis malleifera Fowler, 1895), in the subtropical region of Florida (U.S.A.), have verified that these treehoppers, like the ones in the present work, are less abundant during fall (September to December on the North Hemisphere). WOOD (1976) suggests synchronism between the life history timing of Platycotis vittata Fabricius, 1803 and the growth pattern of its host plant, Quercus sp.: this treehopper has two yearly generations, each of them being in direct temporal association with one of the two fases of seasonal growth of the host plant.

In figure 2 one can clearly see a decrease in the percentage of plants with nymphs along the summer of 1981. This may suggest a decrease in the number of 

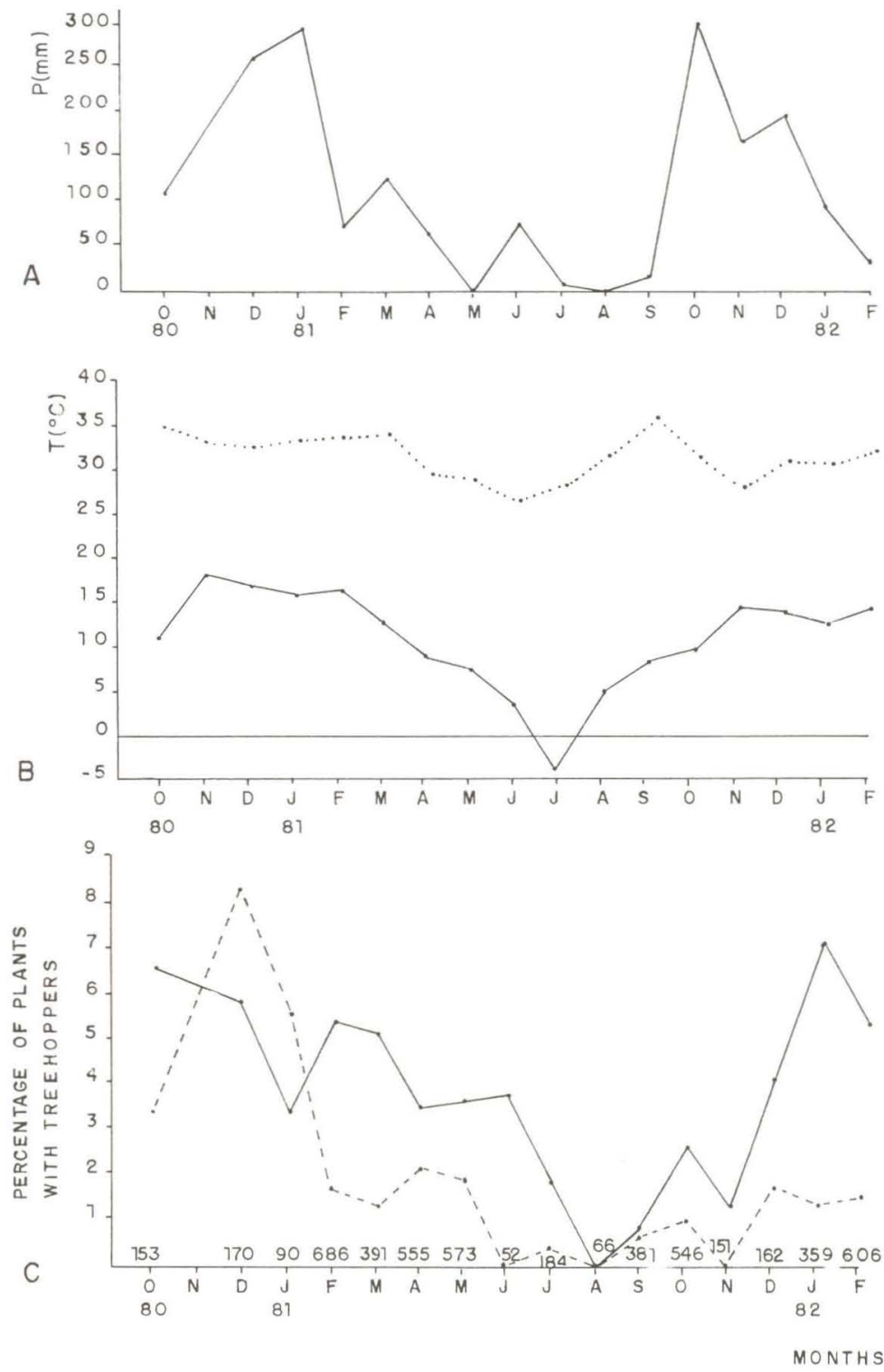

Fig. 2. Climatic data and frequency of the presence of treehoppers on cerrado plants of Reserva Biológica de Moji-Guaçu. (A) Total precipitation for each month; (B) maximal temperature (doted line) and minimal temperature (continuous line) for each month; (C) frequency of the presence of nymphs (broken line) and adults (continuous line). In C, close to the abscissa is the number of plants studied in each month. No observations were made in November, 1980. 
nymphs. The weather data of this season (December, 1980 to March, 1981) show high levels of precipitation and high levels of minimal (above $15^{\circ} \mathrm{C}$ ) and higher maximal temperature. These climatic factors may promote hiotic mortality factors (pathogens, specially fungi and entomophagous insects, whether parasites or predators) (DEBACH 1964; HUFFAKER \& MESSENGER 1976). Although the life histories of individual treehopper species were not analysed here, mortality of nymphs and adult treehoppers due to mycotic diseases were observed. In the same way, predation and parasitism were observed in the studied area, apparently contributing to the reduction of treehoppers.

The marked decrease in the frequency of adult treehoppers in host plants in the cerrado during August, 1981, was probably due to a frost that occurred along the last days of July of that year. Considering that this decrease began well before August and that immediately afterwards it was followed by a marked recuperation in the frequency of adult treehoppers, seemingly the frost had just a temporary effect, though intense, on the fauna of these homoptera. It is suggested (Dr. T.K. Wood, personal communication) that some eggs may have been dormant and hatched with increasing temperature. FUNKHOUSER (1917), in a work carried out in a temperate zone, points out that frost can kill treehoppers, while GOTW ALD (1968) shows that the number of individuals of Vanduzea arquata Say, 1830 decreases in winter, though he does not explain the cause of this populational decline.

Also, frosts in subtropical cerrados may indirectly alter the life cycle of the treehoppers, considering that the harm caused to the host plants can be severe (Silberbauer-GotTsberger et al. 1977). During the weeks that immediately followed the frost at the RBMG, it was observed the occurrence of blackening and falling of the foliage of most of the plants. Though they might have suffered some harm due to the frost, some plant species did not loose leaves. Among these, the most prominent were the species of the families Asteraceae and Myrtaceae. Silberbauer-GotTsberger et al. (1977) have classified as "mildly harmed" by frosts the plants of the family Myrtaceae, which were studied at a cerrado close to the city of Botucatu (São Paulo). From one and a half to two months after the frost almost all plants of the cerrado at the RBMG were sprouting anew.

Concerning the treehopper nymphs, the greater abundance occurred through December, 1980, and January, 1981, followed by a quick reduction during fall. After the frost in July, 1981, few plants exhibit nymphs and these frequencies were not the same as the preceding year, while the frequencies of adults were. One should note that some species of plants suffered severely the effects of the frost, only sprouting again after two months. Thus, through the months following the frost, in addition to a fewer number of adults, it seems that there were also less host plants suitable for oviposition and to sustain treehopper nymphs.

FUNKHOUSER (1917) and WOOD \& PATTON (1971) suggest that most of the species of treehoppers living in temperate regions overwinter as eggs. In fact, many temperate treehoppers have life histories that are tightly coordenated with the phenology of their host plants (WOOD 1993). Hence, the treehoppers and their host plants are well adapted to survive severe adverse climatic conditions. This 
situation is in contrast to what is known about tropical and subtropical treehoppers, which tend to breed throughout the whole year, or to endure the adverse seasons as adults (WOOD 1984, 1993).

\section{CONCLUSIONS}

The moderate degree of host specialization among the treehopper species suggests that the distribution of some of them reflects the distribution of suitable host plants in the cerrado.

There is neither strong evidence supporting seasonal differences in the richness of the treehoppers in the community studied, nor for significant differences in the composition of the community of treehoppers between winter and summer. These results argue against the idea of a seasonal specialization where the same or different resources are used by diverse species in the different seasons of the year. The results also suggest that adult individuals of the more characteristic species of the community are active throughout the year, apparently without depending on diapause or dormancy during the immature stages - particularly eggs - during the less favorable periods of the year.

There seems to be a specialization, or at least a preference, in the studied community of treehoppers, for certain families of host plants and, among these, for some specific species. That means that certain species of treehoppers can be found almost exclusively associated with one to a few species of plants, generally of the same botanical family. On the other hand, there are other non-specialist species of treehoppers that can be found on several plant species, almost always belonging to distinct families.

ACKNOWLEDGMENTS. I am grateful to W.W. Benson for orientation and helpful comments on the manuscript. The staff of the Departamento de Botanica, Instituto de Biologia. Universidade Estadual de Campinas (UNICAMP) and D.B. Falkenberg identified some of the plants. A.M. Sakakibara and R. Corbetta of the Departamento de Zoologia, Universidade Federal do Paraná identified the trechoppers. T.K. Wood and two anonymous reviewers made suggestions on the manuseript. Financial support was provided by grants from the CNPq and CAPES. This work is part of my Master's Thesis at the Programa de Pós-Graduação em Ecologia. Instituto de Biologia. UNICAMP.

\section{REFERENCES}

BRUES, C.T. 1972. Insects, food, and ecology. New York, Dover, 466p.

DEBACH, P. 1964. Biological control of insect pests and weeds. London, Chapman and Hall, 844p.

DEITZ, L.L. 1975. Classification of the higher categories of the New World treehoppers (Homoptera: Membracidae). NC Agric. Exp. Stn. Tech. Bull. 225: $1-177$.

Dietrich, C.H. \& L.L. Deitz. 1991. Revision of the Neotropical treehopper tribe Aconophorini (Homoptera: Membracidae). NC Agric. Res. Ser. Tech. 
Bull. 293: 1-134.

Erten, G. 1971. Habitat tlora of Fazenda Campininha, São Paulo, Brazil, p. 157-202. In: M.G. Ferri (ed.). Simpósio sohre o cerrado. São Paulo, Edgard Blücher \& Editora da Universidade de São Paulo, 424p.

Funkhouser, W.D. 1917. Biology of the Membracidae of the Cayuga Lake

Basin. Cornell Univ. Agric. Exp. Stn. Mem. 11: 117-445. . 1950. Homoptera, Family Membracidae. Gen. Insect. 208: 1-383.

Gotwald JR., W.H. 1968. Food gathering behaviour of the ant Camponotus noveboracensis (Fitch) (Hymenoptera: Formicidae). J. N.Y. Entomol. Soc. 76: $278-296$.

Havilland, M.D. 1925. The Membracidae of Kartabo. Zoologica, New York, 6: $229-290$.

HufFaker, C.B. \& P.S. Messenger. 1976. Theory and practice of biological control. New York, Academic Press, 788p.

LOPES, B.C. 1984. Aspectos da ecologia de membracídeos (Insecta: Homoptera) em vegetação de cerrado do Estado de São Paulo, Brasil. Tese de Mestrado, não publicada, Instituto de Biologia, Universidade Estadual de Campinas, Campinas, $112 \mathrm{p}$.

Lorenzi, H. 1982. Plantas daninhas do Brasil: terrestres, aquáticas, parasitas, tóxicas e medicinais. Nova Odessa, Ed. do Autor, 425p.

Matausch, I. 1910. Entylia Germar and its different forms. J. N.Y. Entomol. Soc. 18: 260-263.

RizzINI, C.T. 1979. Tratado de fitogeografia do Brasil: aspectos sociológicos e florísticos. São Paulo, Editora da Universidade de São Paulo \& Humanismo, Ciência e Tecnologia (HucITEC), 374p.

Silberbauer-Gottsberger, I.; W. Morawetz \& G. Gottsberger. 1977.

Frost damage of cerrado plants in Botucatu, Brazil, as related to the geographical distribution of the species. Biotropica 9: 253-261.

STRÜMPEL, H. 1972. Beitrag zur Phylogenie der Membracidae Rafinesque. Zool. Jahrb. Abt. Syst. Okol. Geogr. Tiere 99: 313-407.

TSAI, J.H. \& D.D. KoPP. 1981. Life history, morphology and taxonomy of Acutalis tartarea (Say) (Homoptera: Membracidae). J. N.Y. Entomol. Soc. 88: $174-185$.

Vuono, Y.S.; L.M. Barbosa \& E.A. Batista. 1981. A Reserva Biológica de Moji-Guaçu. Resumos do XXIII Congresso Nacional de Botânica, Teresina. p. $69-70$.

WoOd, T.K. 1976. Biology and presocial hehaviour of Platycotis vittata (Homoptera: Membracidae). Ann. Entomol. Soc. Am. 69: 807-811.

1977. Role of parent females and attendant ants in the maturation of the treehopper, Entylia bactriana (Homoptera: Membracidae). Sociobiology 2: 257-272.

1984. Life history patterns of tropical membracids (Homoptera: Membracidae). Sociobiology 8: 299-344. 1993. Diversity in the New World Membracidae. Annu. Rev. Entomol. 
38: 409-435.

WOOD, T.K. \& R.L. PATTON. 1971. Egg froth distribution and deposition by Enchenopa binotata (Homoptera: Membracidae). Ann. Entomol. Soc. Am. 64: 1190-1191,

Recebido em 25.III.1995; aceito em 05.X.1995. 